\title{
Improving the Performance of Constructed Wetland Microbial Fuel Cell (CW- MFC) for Wastewater Treatment and Electricity Generation
}

\author{
Yussur D. Abdulwahab ${ }^{1} \quad$ Alaa Kareem Mohammed Malib R. Abbas $^{2}$ \\ 1 Biochemical Eng. Department, AL-Khwarizmi Engineering College, University of Baghdad, Iraq. \\ ${ }^{2}$ Environment and Water Directorate, Ministry of Science and Technology, Baghdad, Iraq. \\ *Corresponding author: Dyussur91@gmail.com, alaauniv@yahoo.com, talibrsh@yahoo.com \\ *ORCID ID: https://orcid.org/0000-0002-4561-5872, https://orcid.org/0000-0002-2765-9142, https://orcid.org/0000- \\ $\underline{0002-1254-9258}$
}

Received 9/9/2019, Accepted 9/2/2020, Published Online First 6/12/2020, Published 1/3/2021

\begin{abstract}
:
The current study deals with the performance of constructed wetland (CW) incorporating a microbial fuel cell (MFC) for wastewater treatment and electricity generation. The whole unit is referred to as CWMFC. This technique involves two treatments; the first is an aerobic treatment which occurs in the upper layer of the system (cathode section) and the second is anaerobic biological treatment in the lower layer of the system (anode section). Two types of electrode material were tested; stainless steel and graphite. Three configurations for electrodes arrangement CW-MFC were used. In the first unit of CW-MFC, the anode was graphite plate (GPa) and cathode was also graphite plate (GPc), in the second CW-MFC unit, the anode was stainless steel mesh (SSMa) and the cathode was a couple of stainless steel plain (SSPc). The anode in the third CW-MFC unit was stainless steel mesh (SSMa) and the cathode was graphite plate (GPc). It was found that the maximum performance for electricity generation $\left(9 \mathrm{~mW} / \mathrm{m}^{3}\right)$ was obtained in the unit with stainless steel mesh as anode and graphite plate as cathode. After 10 days of operation, the best result for COD removal (70\%) was obtained in the unit with stainless steel mesh as anode and stainless steel plain as cathode. The effect of temperature was also investigated. The performance of unit operation for electricity generation was tested at three values of temperature; 30,35 and $40^{\circ} \mathrm{C}$. The best result was obtained at $40^{\circ} \mathrm{C}$, at which the current density obtained was $80 \mathrm{~mA} / \mathrm{m}^{3}$. A culture of Algae could grow in the unit in order to supply the cathodic region with oxygen.
\end{abstract}

Key words: COD removal, Constructed wetland, Electricity generation, Microbial fuel cell, Wastewater treatment.

\section{Introduction:}

Water is an important and critical resource required for industrial processes, food production, energy generation among other applications. The availability and quality of water is extremely affected by climate changes (1). For this reason, wastewater could be treated and used as wash water or for reuse in green areas (2). Intensive chemical, physical and biological technologies are normally used for wastewater treatment. These technologies are featured with considerable power consumption and relatively high cost. Extensive treatment technologies on the other hand are featured with low power consumption, low cost but very effective. One of the extensive biological technologies which takes more attentions by the researchers is constructed wetlands $(\mathrm{CW})$. It has been considered environment friendly and the most cost-effective technology used for this purpose (3). Wang et al. reported that, since 1970s, constructed wetlands (CW) have been designed and utilized worldwide to treat a variety of wastewaters including domestic sewage, dairy washings, agricultural runoff, mine drainage, urban and motorway storm runoff, and landfill leachate (4). In constructed wetlands $(\mathrm{CW})$, the treatment occurs which includes adsorption and filtration by plants as well as aerobic/anaerobic degradation by microorganisms (5). Figure 1 illustrates the operation of CW. Thus, the reactions that occur in two zones aerobic and anaerobic can be utilized for the implementation of microbial fuel cells (MFCs). 


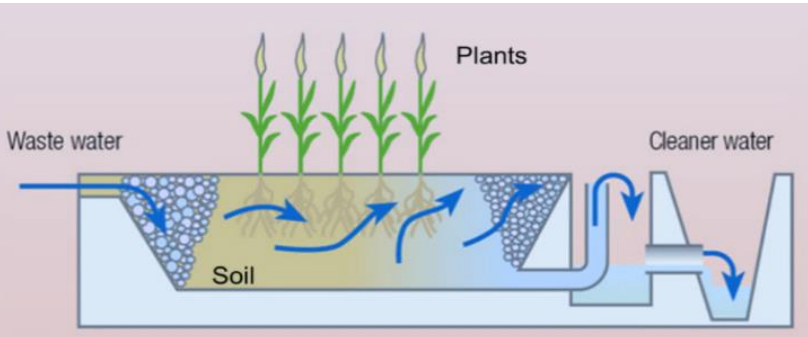

Figure1. Operation of Concentrated wetland CW

In MFC, chemical energy released from the organic substances is used to produce electricity with the help of electroactive microorganisms (Bacteria). Potter was the first researcher who retrieved electricity from MFC using Escherichia coli culture (6). Usually bacterial community is present along with organic substances which are placed in anodic compartment to produce electrons due to the biological process. The electrons are released from this process then transferred to cathode through external circuit that causes current. The anodic compartment should be maintained under anaerobic conditions (absence of electron acceptor) because oxygen inhibits electricity generation whereas cathodic compartment is exposed to oxygen atmosphere (7).

The integration between CWs and MFs is possible since the wastewater present in the concentrated wetland provides the organic matter which leads to generate gradient in redox reactions between two layers; upper layer of treatment bed (aerobic zone) and lower layers (anaerobic). As a result, MFC is implemented in CWs and makes up CW-MFC system. This system can produce electricity while wastewater is treated. Moreover, the integrated system (CW-MFC) may exert other useful effects on CWs, such as a reduction of greenhouse gas emissions, decrease in surface treatment requirements and clogging. Many factors play an important role in the determining the performance of the (CW-MFC system) in both the electricity generation and the wastewater treatment (chemical oxygen demand (COD) removal) (6). These factors are organic substances, design, microorganisms and material of electrodes. The material and shape of the electrodes have great effect in optimizing the power generated in the CWMFC system. Electrode material should have several properties in order to be effective as an electrode (7). It should exhibit beneficial electrochemical properties (favourable electron transfer) as well as economical and have stable mechanical properties in conjunction with a large surface area, which lead to give large current densities.
In most of the constructed wetland microbial fuel cell (CW-MFC), carbon based materials were used as electrodes (e.g., activated carbon granules and graphite) due to their high specific surface area, corrosion resistance and low cost (7). Boets used anode and cathode as graphite plate and obtained $15.7 \mathrm{~mW} / \mathrm{m}^{2}$ and $65 \%$ COD removal (8). Luo et al. used anode and cathode as granular activated carbon and obtained $9.4 \mathrm{Mw} / \mathrm{m}^{3}$ and $60 \%$ COD removal (9). Jung et al. used anode and cathode as carbone felt to obtain $6.12 \mathrm{Mw} / \mathrm{m}^{2}$ (10). Logan et al., used granular graphite as anode and carbon cloth coated with platinum as cathode and obtained $320.8 \mathrm{Mw} / \mathrm{m}^{3}$ (11). Mehdinia et al. (12) used flat graphite as anode and Pt- coated titanium as cathode, the obtained power was 370.8 $\mathrm{Mw} / \mathrm{m} 3$. Kumar et al. (13) in their study used carbon nano tube (CNT) as electrode. The performance of CW-MFC using CNT based electrodes compared with plain graphite electrode and it was found that CNT based electrodes showed six times greater power density compared to graphite electrodes. The aim of this work is to examine the performance of CW-MFC for wastewater treatment (COD removal) and electricity generation using electrodes made of grid stainless steel and compare it with another types of electrodes using plain stainless steel and also graphite electrodes.

\section{Materials and Methods: Wastewater preparation}

A synthetic wastewater with the desirable amount of glucose as a carbon source was prepared and used throughout this work. The wastewater composition was adopted from the literature (14). The composition of the synthetic wastewater was as follows: Varying amount of Glucose $(0.25 \mathrm{~g} / \mathrm{L}$; $0.5 \mathrm{~g} / \mathrm{L} ; 0.75 \mathrm{~g} / \mathrm{L})$, Meat extract $(0.25 \mathrm{~g} / \mathrm{l})$, Peptone $(0.4 \mathrm{~g} / \mathrm{l}), \mathrm{FeSO}_{4} .7 \mathrm{H}_{2} \mathrm{O}(0.02 \mathrm{~g} / \mathrm{l}), \mathrm{NH}_{4} \mathrm{Cl}(0.2 \mathrm{~g} / \mathrm{l})$,

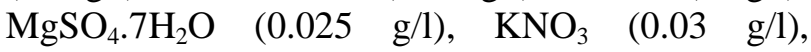
$\mathrm{K}_{2} \mathrm{HPO}_{4} .3 \mathrm{H}_{2} \mathrm{O}(0.045 \mathrm{~g} / \mathrm{l})$ and $(1 \mathrm{ml} / \mathrm{l})$ trace solution. The trace solution is composed of; $\mathrm{CaCl}_{2} \cdot 6 \mathrm{H}_{2} \mathrm{O}$ $(0.15 \mathrm{~g} / \mathrm{l}), \mathrm{H}_{3} \mathrm{BO}_{3}(0.15 \mathrm{~g} / \mathrm{l}), \mathrm{FeCl}_{3} \cdot 6 \mathrm{H}_{2} \mathrm{O}(1.5 \mathrm{~g} / \mathrm{l})$, $\mathrm{CuSO}_{4} .5 \mathrm{H}_{2} \mathrm{O} \quad(0.03 \mathrm{~g} / \mathrm{l}), \quad \mathrm{KI} \quad(0.03 \mathrm{~g} / \mathrm{l})$ and $\mathrm{ZnSO}_{4} \cdot 7 \mathrm{H}_{2} \mathrm{O}(0.12 \mathrm{~g} / \mathrm{l})$.

\section{Activated sludge}

The activated sludge (which contains mixed culture to provide microorganism necessary for oxidation of the organic compounds) was obtained from Al-Rustomia wastewater treatment plant located in the south of Baghdad city. 


\section{Construction of CW-MFCs}

Three symmetrical lab-scale of constructed wetland microbial fuel cells (CW-MFC) were designed using glass basin, the dimensions of each were (length $\mathrm{L}=29 \mathrm{~cm}$, width $\mathrm{W}=28.5 \mathrm{~cm}$, and height $\mathrm{H}=30 \mathrm{~cm}$ ). The system $\mathrm{CW}-\mathrm{MFC}$ is designed with two sample points; one at the anode region, $4 \mathrm{~cm}$ from the bottom and the other at the cathode region, $17 \mathrm{~cm}$ from the bottom. Figure 2 shows the schematic diagram of the laboratory configuration of CW- MFC system. The basin was filled with gravels (of different diameters 3- $7 \mathrm{~mm}$ ) to about $1 \mathrm{~cm}$ from the bottom, then the anode was placed above the gravel followed by another layer of gravel $(11 \mathrm{~cm}$ thick). Glass wool of $(1 \mathrm{~cm}$ thick) was placed at $12 \mathrm{~cm}$ from the bottom to separate the anode from the cathode. Another layer of gravel of (12 cm thick) was positioned above the glass wool, then the cathode was placed above the gravel with one surface open to the atmosphere. The gravel was used as a supporting medium and to promote even distribution of wastewater into the system. The types of anode material employed in this study were; (graphite plate (GP) and stainless steel mesh (SSM), while the cathode materials were; graphite plate (GP) and a couple of stainless steel plains (SSP). The dimensions of each electrode (anode or cathode) were $190 \mathrm{~mm}$ length, $95 \mathrm{~mm}$ width and $3 \mathrm{~mm}$ thick. Figure 3 shows the types of electrode materials used in this work. In the first unit of CWMFC, the anode was graphite plate (Gpa) and cathode was also graphite plate (GPc). The subscript letters (a and c) refer to anode and cathode, respectively. This unit is referred to as (Gpa-GPc-CW-MFC). In the second CW-MFC unit, the anode was stainless steel mesh (SSMa) while the cathode was a couple of stainless steel plain $(\mathrm{SSPc})$ and the unit is referred to as (SSMa-SSPc(W-MFC). The anode in the third CW-MFC unit was stainless steel mesh (SSMa) and the cathode was graphite plate $(\mathrm{GPc})$, the unit is referred to as (SSMa-GPc-CW-MFC). The total volume of each CW-MFC unit was $15 \mathrm{~L}$ with a liquid volume of 10 L. One end of each electrode was connected with copper wire and properly sealed with an epoxy material. These wires were used to connect both the anode and the cathode to an external electrical variable resistance $(0-10 \mathrm{~K} \Omega)$. The voltage output of CW-MFC was measured and recorded using Digital multi-meter (Mastech MAS-345).

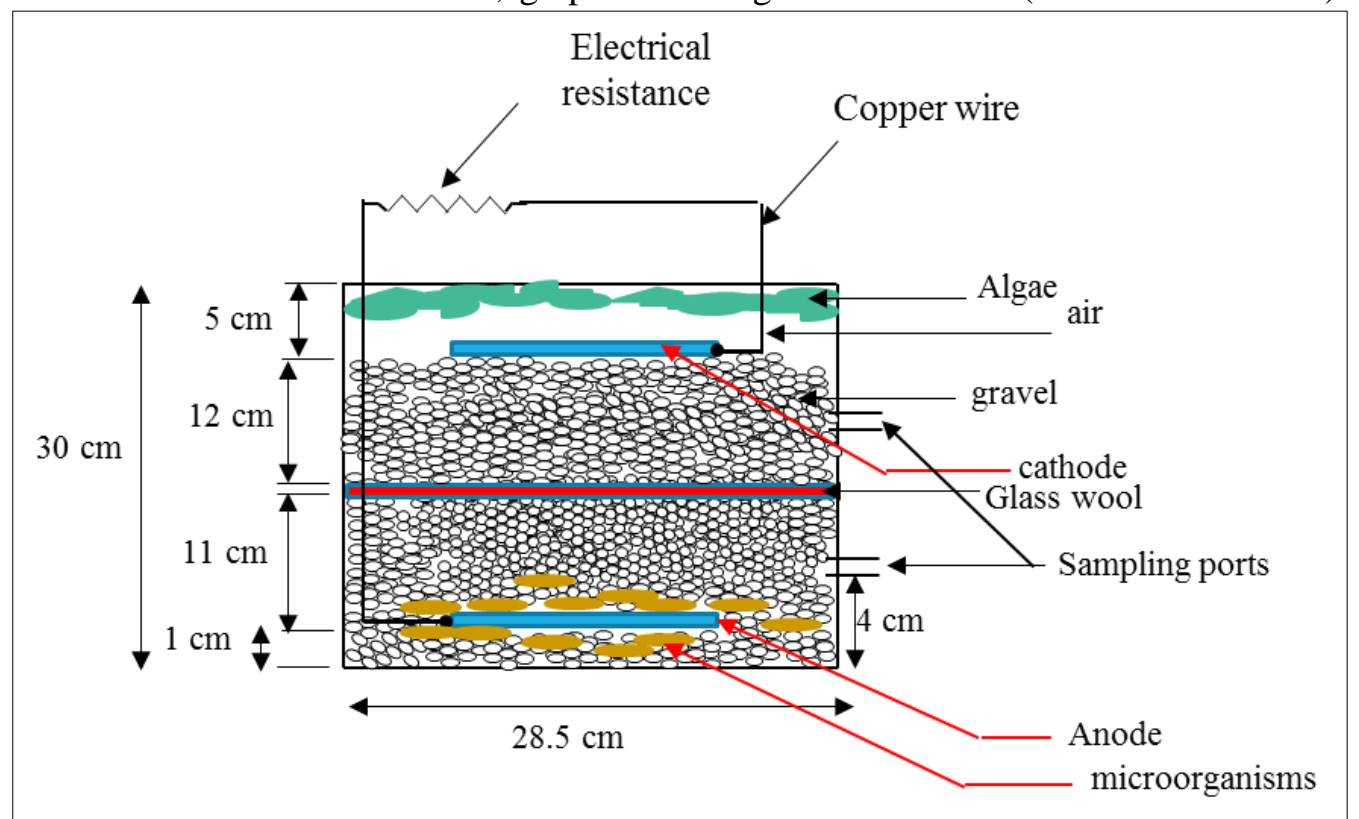

Figure 2. Schematic diagram of laboratory CW- MFC system 


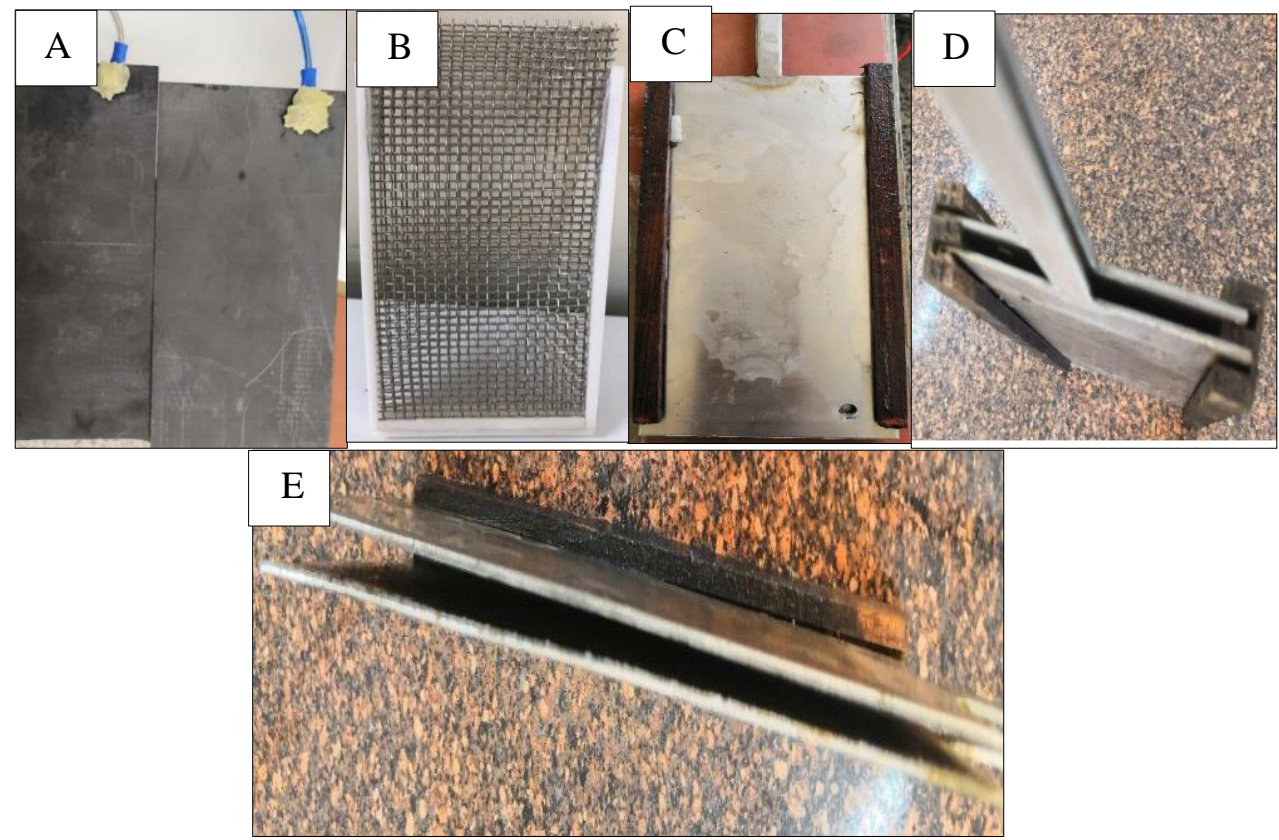

Figure 3. Types of used electrodes (A- Graphite plate electrode (GP), B- Stainless steel mesh electrode (SSM) and (C- front, D- top and E- side) view of couple stainless steel plains (SSP)

\section{Experimental work Experimental procedure}

The CW-MFCs were developed and investigated in a closed-circuit mode for COD removal and electricity generation from the synthetic wastewater. The CW-MFCs were inoculated with $1500 \mathrm{ml}$ activated sludge in the anodic region. In order to provide the CW-MFC with the oxygen required for the process, researchers used either mechanical air pump, plant or both to equip the system with oxygen $(15,16,17)$. In this work, algae were used to provide the cathode region with the oxygen necessary for the process to improve the cell reaction. All the experiments were done in a fed-batch mode for ten days (after the growth of algae). The three systems I, II, III were set outdoor and these systems were equipped with oxygen by mechanical aeration because the activated sludge was originally aerobic and since the water contains nitrate the bacteria start the denitrification process. In this process, bacteria take the oxygen and release the nitrogen as a gas and the released nitrogen gas cause the flotation of bacteria to the surface which is unwanted. This source of air was removed after the growth of algae. In the presence of sunlight and $\mathrm{CO}_{2}$ from the atmosphere, algae (micro and macro) can be seen on the surface of the water after 3-5 days. Figure 4 shows the growth of algae into the basin of the CW-MFC system.

The CW-MFCs were operated in a batch mode. At the beginning of operation each CW-MFC was filled with synthetic wastewater with specific initial COD. For studying the removal of COD with time, $(10 \mathrm{ml})$ water samples were collected from the cathodic region of each particular CW-MFC (after the growth of algae) via sampling point. The concentration of COD was analyzed using $\mathrm{HACH}$ DR 2800 colorimeter. The COD was determined according to standard methods (HACH DR 2800 colorimeter). The voltage (V) and current were measured using a digital multi-meter (MAS-345, USA) on a fixed resistance. Once CW-MFC was established, the polarization curve was prepared using different resistances between $(0-10 \mathrm{~K} \Omega$ ) for each CW-MFC unit in order to specify a value of the resistance which gives maximum power generation from the system. The voltage was measured four times a day. The current density (I) and power density (P) were determined through basic electrical calculations using standard relations. 


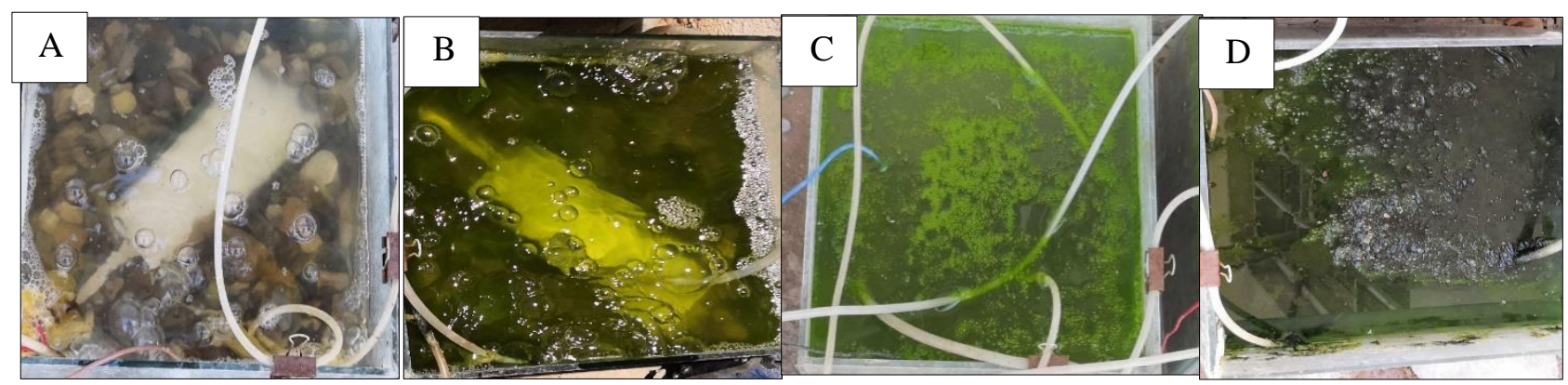

Figure 4. The growth of algae into CW-MFC (A- first day, B- third days, C- fifth day and D- eighth day).

\section{Algal analysis}

Algae play many important and beneficial roles in freshwater environments. They produce oxygen and consume carbon dioxide, act as the base for the aquatic food chain, remove nutrients and pollutants from water, and stabilize sediments (18). In the three systems, algae growth can be seen after 3-5 days from the start up time. Algae is used to provide the system with the oxygen necessary for the process in the cathodic region which reduce the cost of utilizing artificial aeration and algae give better oxygen distribution than the artificial aeration in which oxygen distribution is limited on the surface of the system (19). A sample from the algae community that was growing in the cathodic region was analyzed by composite optical microscope (Zeiss, Germany). The algae species found are; Chlamydomonas ehrenbergii Gorozhankin, Chlorella ellipsoidea, Aphanocapsa Endophtica, Microcystis aeruginosa, Oscillatoria limnetic, Euglena sp., Haematococcus sp. and Microcystisflos-aquae as shown in Fig. 5.

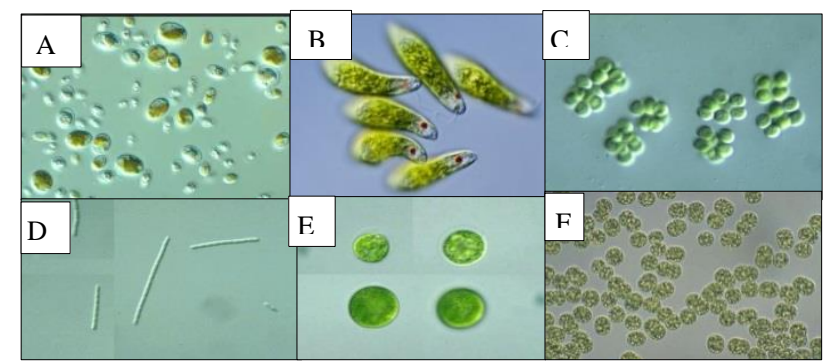

Figure 5. Cultures of algae growing in the system; A-Chlorella ellipsoidea, B- Euglena Sp., C- Microcystis flos-aquae, D- Oscillatoria Limnetica, E- Haematococcus and F-Microcystis Aeruginosa.

\section{Results and Discussion: Polarization curve}

Polarization curves represent a powerful tool for the analysis and characterization of fuel cells. It represents the variation of both the voltage and the power density against the current density. In this study, the polarization curve was prepared for each configuration of CW-MFC using variable resistance from $(0-10 \mathrm{~K} \Omega)$ to indicate the best resistance for each type of the electrodes so as to obtain the maximum value of electrical power. The power $(\mathrm{P})$ was determined from the basic electrical calculations (Eq.1)

$\mathrm{P}=\mathrm{I} * \mathrm{~V}$

Where $\mathrm{P}$ is the power generated in (Mw), I is the current in (Ma) and V is cell voltage in (Mv). Since the electrons that used for power generation were generated at the anode, the power density $\left(\mathrm{P}_{\mathrm{d}}\right.$, $\left.\mathrm{W} / \mathrm{m}^{3}\right)$ and current density $\left(\mathrm{A} / \mathrm{m}^{3}\right)$ were determined by dividing the value of power $(\mathrm{P})$ and the current (I) by the volume of anode zone (v) which equal to $0.005 \mathrm{~m}^{3}$ as illustrated in Eqs. (2 and 3) (20).

$\mathrm{P}_{\mathrm{d}}=\frac{\mathrm{P}}{\mathrm{v}}$
$\mathrm{I}_{\mathrm{d}}=\frac{\mathrm{I}}{\mathrm{v}}$

Figure 6 shows the polarization curve for graphite electrodes (anode and cathode) in the configuration (Gpa-GPc-CW-MFC). The maximum power density $\left(\mathrm{P}_{\mathrm{d}}\right)$ obtained was about $\left(2.025 \mathrm{Mw} / \mathrm{m}^{3}\right)$ which occurs at output voltage $\mathrm{V}(225 \mathrm{Mv})$ and current density $I_{d}\left(9 \mathrm{Ma} / \mathrm{m}^{3}\right)$. 


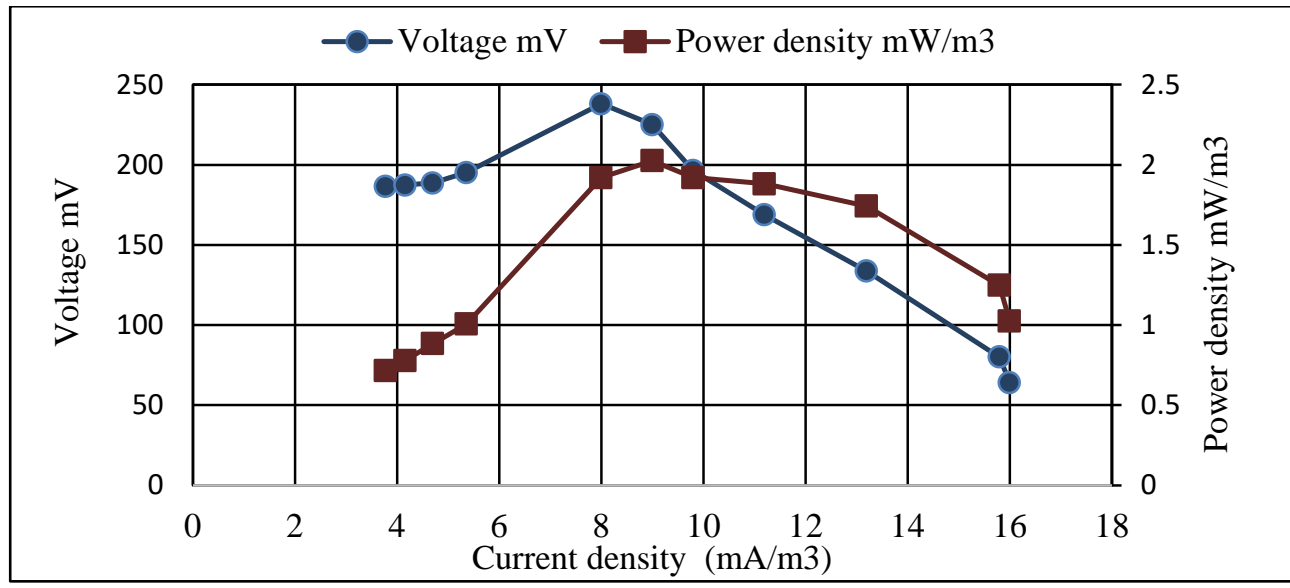

Figure 6. Polarization curve for the configuration (Gpa-GPc-CW-MFC).

The optimum electrical resistance can be calculated from eq. $(4 \& 5)$ :

$$
\begin{aligned}
& \mathrm{I}=\mathrm{I}_{\mathrm{d}} * \mathrm{U} \\
& \mathrm{R}=\frac{\mathrm{V}}{\mathrm{I}}
\end{aligned}
$$

$\mathrm{I}=9 * 0.005=0.045 \mathrm{Ma}$

$$
\mathrm{R}=\frac{225}{0.045}=5000 \Omega
$$

From the calculation above, it was noted that the maximum power density for (Gpa-GPcCW-MFC) can be obtained at electrical resistance value of $(5 \mathrm{~K} \Omega)$. Figure 7 and 8 show the polarization curves for both configurations (SSMaGPc-CW-MFC) and (SSMa-SSPc-CW-MFC) respectively. In Fig.6, the maximum power density $\left(\mathrm{P}_{\mathrm{d}}\right)$ obtained was about $\left(8.9 \mathrm{Mw} / \mathrm{m}^{3}\right)$ which occurs at output voltage $\mathrm{V}(210 \mathrm{Mv})$ and current density $\mathrm{I}_{\mathrm{d}}$ $\left(42 \mathrm{Ma} / \mathrm{m}^{3}\right)$. In Figure7, the maximum power density $\left(\mathrm{P}_{\mathrm{d}}\right)$ obtained was about $\left(5 \mathrm{Mw} / \mathrm{m}^{3}\right)$ which occurs at output voltage $\mathrm{V}(160 \mathrm{Mv})$ and current density $I_{d}\left(32 \mathrm{Ma} / \mathrm{m}^{3}\right)$. The maximum power density in both configurations (SSMa-GPc-CW-MFC) and (SSMa-SSPc-CW-MFC) are obtained at $(1 \mathrm{~K} \Omega)$.

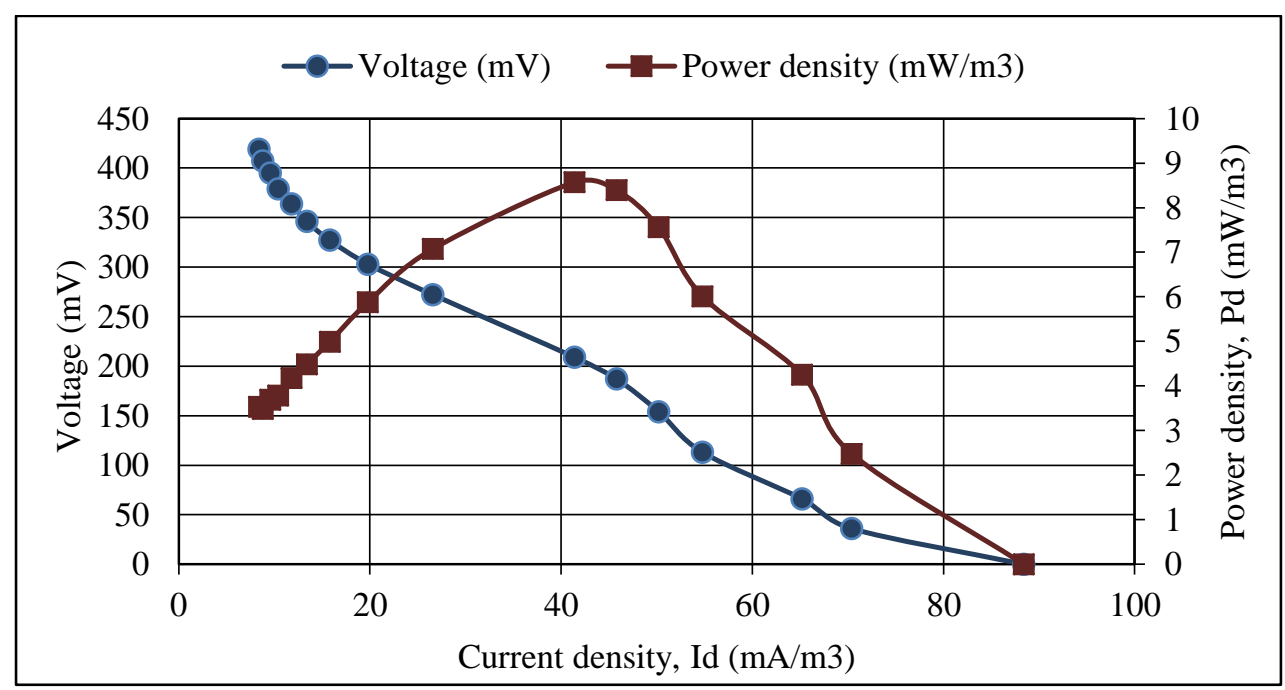

Figure7. The polarization curve for the configuration (SSMa-GPc-CW-MFC). 


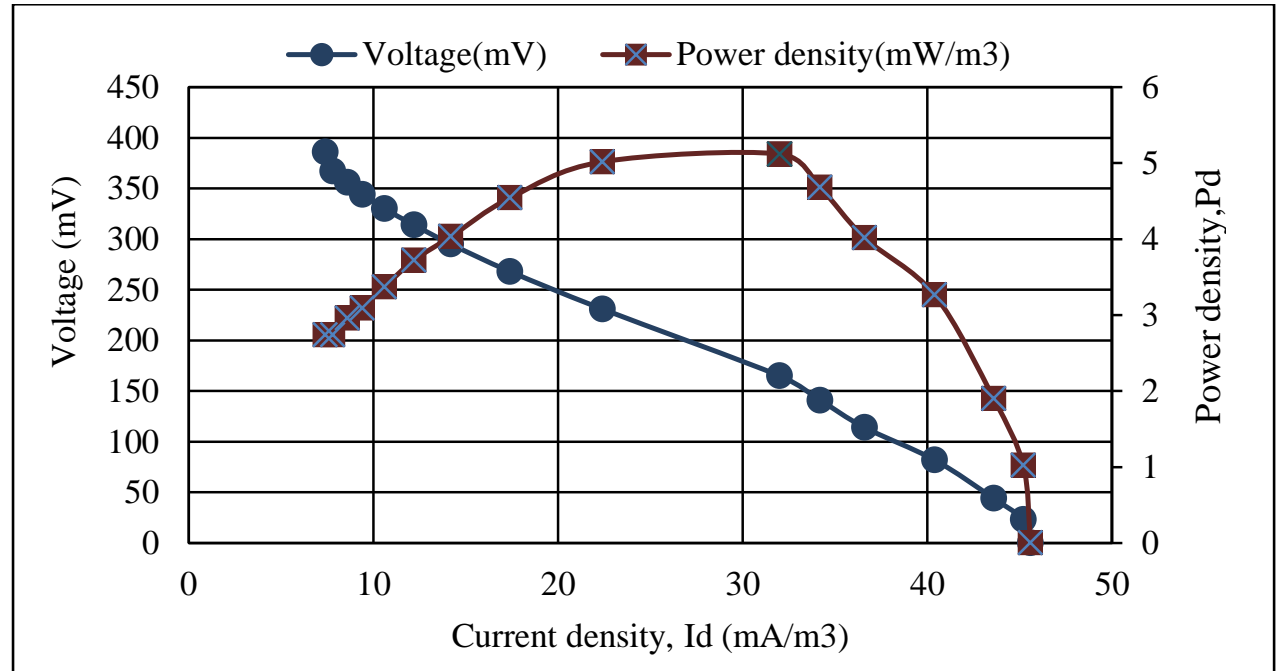

Figure 8. The polarization curve for the configuration (SSMa-SSPc-CW-MFC)

\section{Electricity generation}

\section{Effect of glucose concentration}

In order to investigate the effects of the glucose concentration on the bioelectricity generation performance of CW-MFC with stainless steel mesh as an anode and graphite plate as cathode (SSMa-GPc-CW-MFC), a series of synthetic wastewater was prepared with different glucose concentrations $(0.25 \mathrm{~g} / \mathrm{l}, 0.5 \mathrm{~g} / \mathrm{l}$ and $0.75 \mathrm{~g} / \mathrm{l})$ to analyze the power density generated by the $\mathrm{CW}$ MFC system. The power density and current density were calculated for the three values glucose concentrations. Figure 9 illustrates that the higher power density and current density can be obtained for CW-MFC with glucose concentration of 0.25 $\mathrm{g} / \mathrm{l}$. The reason might be that high concentrations of glucose limit the bacterial growth by inhibiting proteinacious enzymes; by reducing a cell's ability to breakdown and catabolism of proteinacious resources. In addition, the average voltages of the system decreased with the increase of the substrate concentration, this may be attributed to its inhibitory effects as the formation of byproducts such as lactic acid, formic acid and acetic acid at high concentration of glucose, which inhibit growth of microorganisms, possess deteriorating effect on the metabolic activities (21).

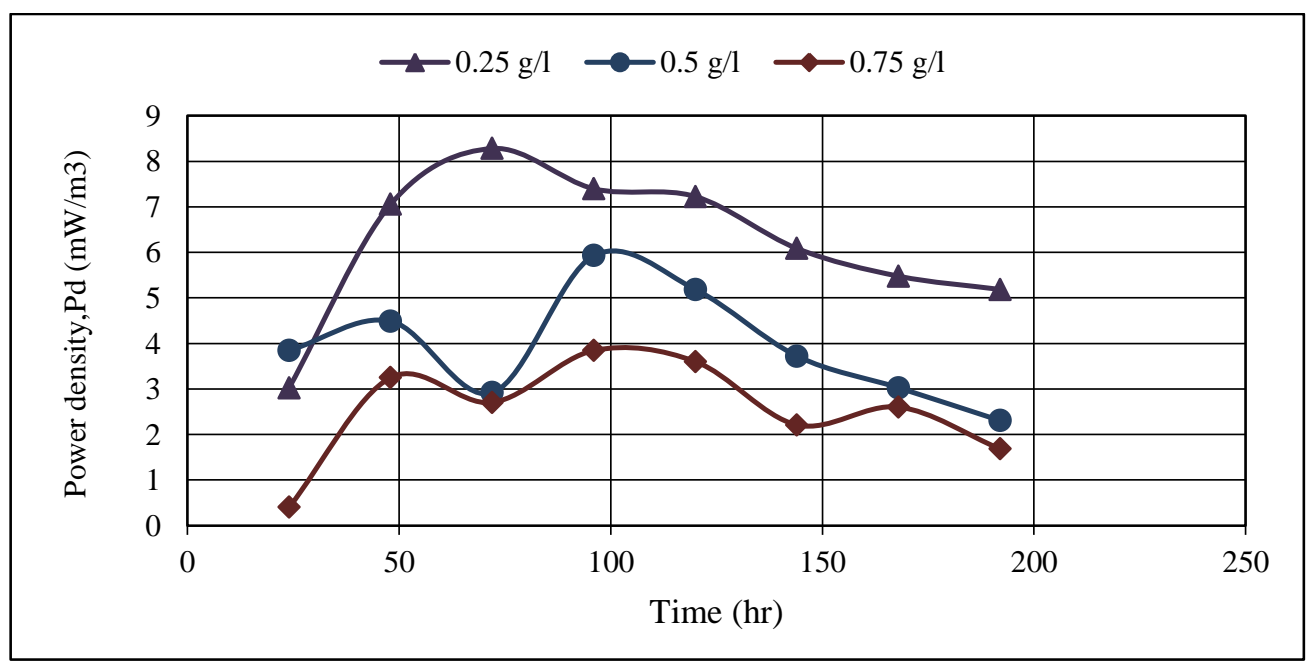

Figure 9. Power density profile in closed circuit for CW-MFC stainless steel mesh as an anode and graphite plate as cathode (SSMa-GPc-CW-MFC).

\section{Effect of clectrode materials}

Synthetic wastewater was prepared with glucose concentration of $0.25 \mathrm{~g} / \mathrm{l}$ to analyze the cell voltages generated by the three configurations; (Gpa-GPc-CW-MFC), (SSMa-GPc-CW-MFC) and (SSMa-SSPc-CW-MFC). Figure 10 shows that the highest power density was $14.4 \mathrm{Mw} / \mathrm{m} 3$ generated in (SSMa-GPc-CW-MFC) whereas the lowest was $7.9 \mathrm{Mw} / \mathrm{m} 3$ in (Gpa-GPc-CW-MFC). This may be due to the high specific surface area of SSM anode compared with that of GP anode. Furthermore, the electrical conductivity of stainless steel is higher 
than that of graphite. Also the biocompatibilty of microorganisims is higher to stainless steel than graphite plates (22). So the (SSMa-SSPc-CW-MFC) system performed is better as compared to (GpaGPc-CW-MFC) system.

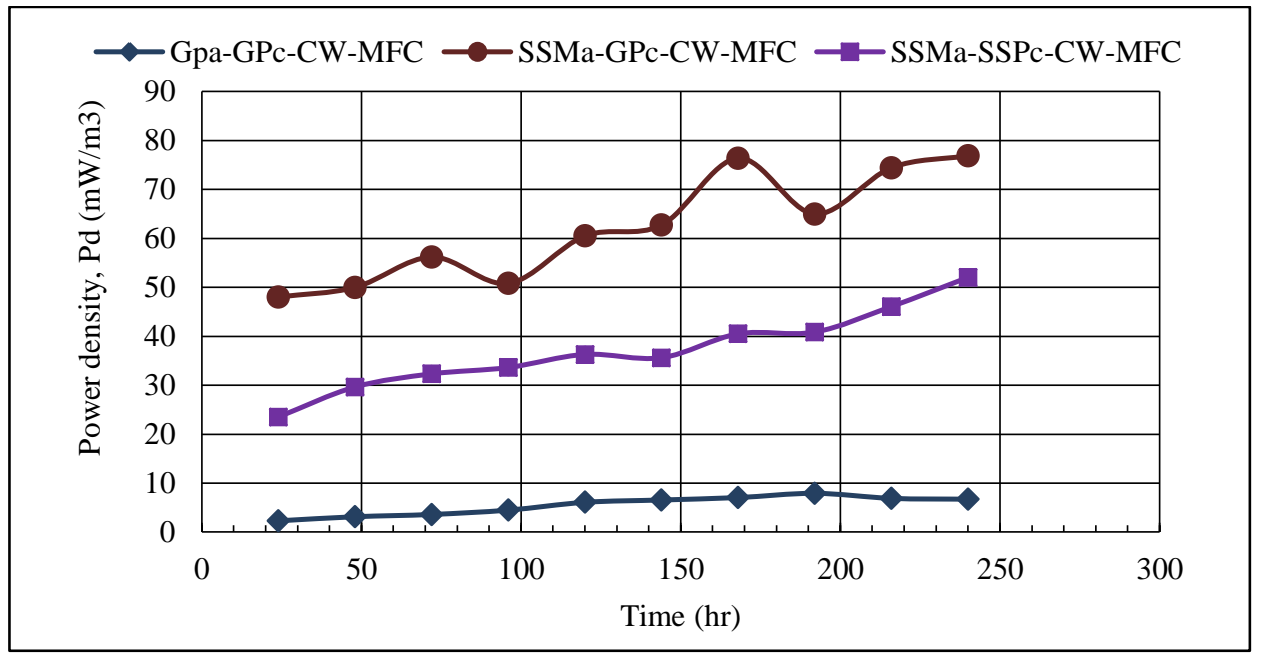

Figure 10. Power density profile with time for different electrode materials with aeration.

\section{Effect of temperature}

To investigate the effect of temperature on the performance of (SSMa-GPc-CW-MFC) system, an experiment was done at three different temperatures; 30,35 and $40{ }^{\circ} \mathrm{C}$. Figure 11 illustrates that, temperature $40{ }^{\circ} \mathrm{C}$ gives the highest power density. From this observation it can be seen that the temperature has a large influence on the performances of a CW-MFC because it changes the conductivity of the substrate and the microorganism activity of microbial community (23). The internal resistance of the CW-MFC decreases by increasing temperature. That can be explained by the fact that ionic conductivity increases with temperature and therefore decreases the resistance (24).

The temperature during the initial growth phase of biofilm must be favorable for these bacteria. Once the biofilm is formed, some microbial species can adjust their metabolism at different temperatures without a significant decrease in performances (25). By increasing the temperature to some extent, CW-MFC operates much better than lower temperatures that can be explained by the following observation: the higher the temperature, the higher the microbial metabolism and the higher the performance and the internal resistance of the MFC decreases by increasing temperature. Furthermore, biofilms grown at higher temperatures tend to have higher electrochemical activity than those at lower temperatures. Thus, operating temperature manipulation provides an effective strategy to reduce MFC start-up time and to improve power output (26).

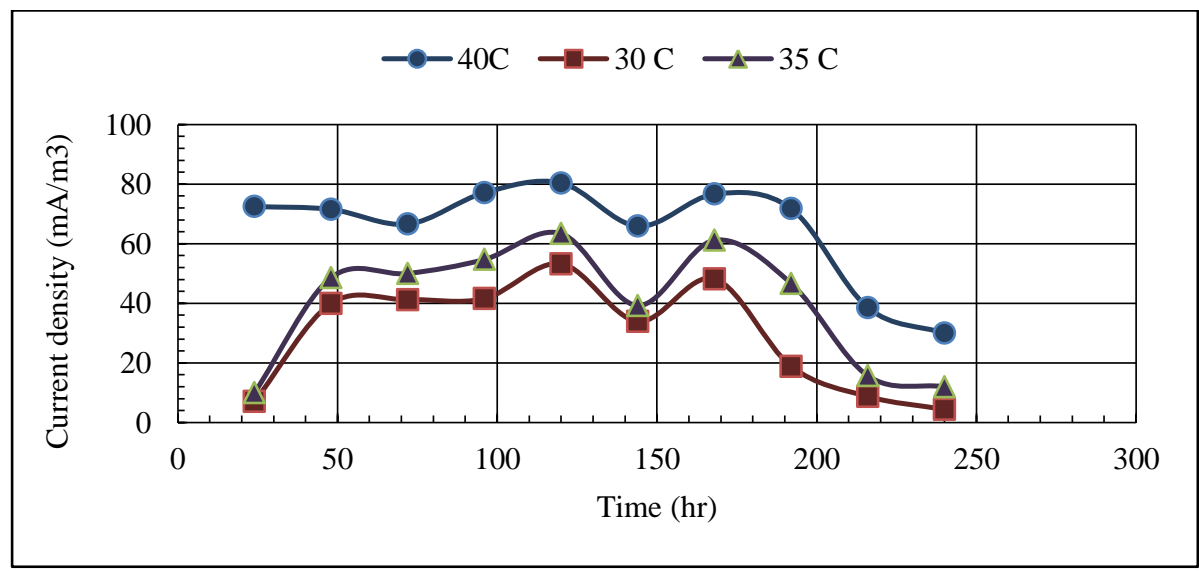

Figure 11. Power density generation with time at different temperatures.

\section{Wastewater treatment}

At the beginning of the operation, the system was fed with synthetic wastewater with glucose concentration $0.25 \mathrm{~g} / \mathrm{l}$ as a main source of carbon. The influent COD of untreated synthetic wastewater was $803 \mathrm{mg} / \mathrm{L}$. The COD removal was 
mainly achieved in the anaerobic region of wetland (anodic region), the organic compounds were oxidized by microorganisms. The COD removal efficiency was calculated using Eq. 6 below:

$C O D=\left[\frac{C_{i}-C_{f}}{C_{i}}\right] * 100 \%$

Where $C_{i}$ is the COD concentration of initial untreated synthetic wastewater, and $\mathrm{C}_{\mathrm{f}}$ is the COD concentration of treated synthetic wastewater $\mathrm{mg} / \mathrm{l}$. Figure 12 illustrates the percentage removal of COD in the three configurations systems. It was noted that the maximum percentage removal of
COD occurs after two days which is equal to about $75 \%$ in both configurations (Gpa-GPc-CW-MFC) and (SSMa-SSPc-CW-MFC), while in configuration (SSMa-GPc-CW-MFC) the maximum percentage of COD removal occurs after five days which is equal to about $60 \%$.

The drop in COD removal with time can be attributed to the death and disintegration of algae which forms a thick layer on the surface of water which lead to increase the COD concentration in the systems.

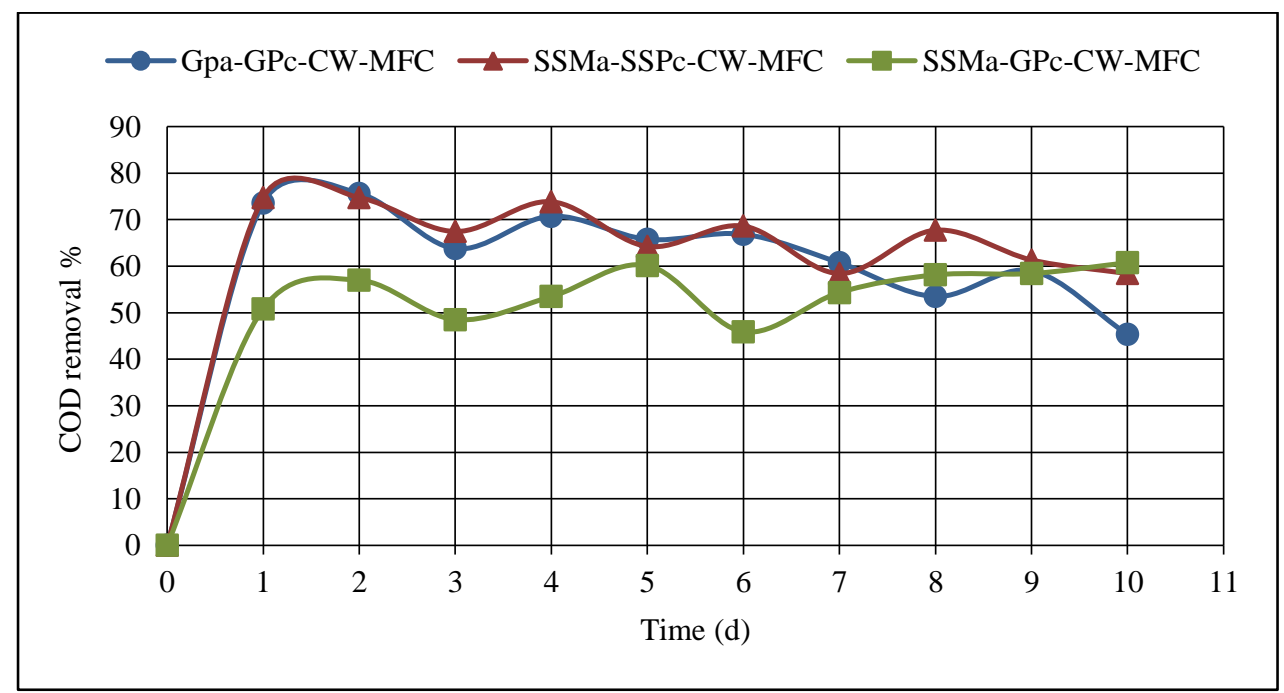

Figure12. The percentage removal of COD with time in different electrode systems.

\section{Conclusions:}

This study elucidates the ability of the CWMFC to produce electrical power while simultaneously treating wastewater. Stainless steel mesh electrode shows higher performance when used as anode with Graphite plate as cathode since it produces higher power density $\left(9 \mathrm{Mw} / \mathrm{m}^{3}\right)$ than graphite electrode $\left(2 \mathrm{Mw} / \mathrm{m}^{3}\right)$ when used as anode. Also, CW-MFC with stainless steel mesh anode is more efficient in COD removal $(60 \%)$ than that of graphite anode (45\%) after 10 days of treatment. Temperature significantly affects the performance of CW-MFC, higher temperatures gives better performance of CW-MFC since it increases the metabolism of microorganisms and reduces internal resistance of the system. The optimum working temperature is $40^{\circ} \mathrm{C}$. Algae can be used to provide enough oxygen required in the aerobic zone reaction of the MFC-CW system.

\section{Authors' declaration:}

- Conflicts of Interest: None.

- We hereby confirm that all the Figures and Tables in the manuscript are mine ours. Besides, the Figures and images, which are not mine ours, have been given the permission for republication attached with the manuscript.

- Ethical Clearance: The project was approved by the local ethical committee in University of Baghdad.

\section{References:}

1. Parkash A. Microbial fuel cells: a source of bioenergy. J Microb Biochem Technol. 2016; 8: 247-255.

2. Rismani-Yazdi H, Carver S M, Christy A D, Tuovinen $\mathrm{O} \mathrm{H}$. Cathodic limitations in microbial fuel cells: an overview. J Power Sources. 2008; 180: 683-694.

3. Santoro C, Arbizzani C, Erable B, Ieropoulos I. Microbial fuel cells: from fundamentals to applications. A review. J Power Sources. 2017; 356: 225-244.

4. Wang H, Luo H, Fallgren $\mathrm{P} H$, Jin $S$, Ren $\mathrm{Z}$ J. Bioelectrochemical system platform for sustainable environmental remediation and energy generation. Biotechnol Adv. 2015; 33:317-34.

5. Li Y, Wu Y, Liu B, Luan H, Vadas T, Guo W, et al. Self-sustained reduction of multiple metals in a microbial fuel cell-microbial electrolysis cell hybrid system. Bioresour Technol. 2015; 192:238-46.

6. Dong Y, Feng Y, Qu Y, Du Y, Zhou X, Liu J. A combined system of microbial fuel cell and intermittently aerated biological filter for energy self- 
sufficient wastewater treatment. Sci Rep. 2015; 5:18070.

7. Myung J, Yang W, Saikaly P, Logan B E. Copper current collectors reduce long-term fouling of air cathodes in microbial fuel cells. Environ Sci: Water Res Technol. 2018; 4:513-9.

8. Boets P, Michels E, Meers E, Lock K, Tack M G, Goethals P L M. Integrated constructed wetlands (ICW): ecological development in constructed wetlands for manure treatment. Wetlands. 2011; 31: 763-771.

9. Luo H, Jenking J, Ren Z. Concurrent desalination and hydrogen generation using microbial electrolysis and desalination cells. Environ. Sci. Technol. 2011; 45: 340-344.

10. Jung S, Regan J M. Comparison of anode bacterial communities and performance in microbial fuel cells with different electron donors. Appl Microbiol Biotechnol. 2007; 77: 393-402.

11. Logan B, Rabaey K. Conversion of Wastes into Bioelectricity and Chemicals by Using Microbial Electrochemical Technologies. Science. 2012; 337: 686-690.

12. Mehdinia A, Ziaei E, Jabbari A. Facile microwaveassisted synthesized reduced 16rapheme oxide/tin oxide nanocomposite and using as anode material of microbial fuel cell to improve power generation. Int $\mathbf{J}$ Hydrogen Energy. 2014; 39:10724-30.

13. Kumar G G, Hashmi S, Karthikeyan C, GhavamiNejad A, Vatankhah- Varnoosfaderani M, Stadler F J. Graphene oxide/carbon nanotube composite hydrogels-versatile materials for microbial fuel cell applications. Macromol Rapid Commun. 2014; 35:1861-1865.

14. Srivastava P, Yadav A K, Mishra B K. The effects of microbial fuel cell integration into constructed wetland on the performance of constructed wetland. Bioresour Technol. 2015; 195: 223-230.

15. Oon Y, Ong S, Ho L, Won Y, Dahalan F A, Oon Y, et al. Synergistic effect of up-flow constructed wetland and microbial fuel cell for simultaneous wastewater treatment and energy recovery. Bioresour Technol 2016; 203: 190-197.
16. Tang C, Zhao Y, Kang C, Yang Y, Morgan D, Xu L. Towards concurrent pollutants removal and high energy harvesting in a pilot-scale CW-MFC: Insight into the cathode conditions and electrodes connection. Chem. Eng. J. 2019; 373: 150-160.

17. Wang X, Tian Y, Liu H, Zhao X, Peng S. Optimizing the performance of organics and nutrient removal in constructed wetland- microbial fuel cell systems. Sci. Total Environ. 2019; 653: 860-871.

18. Mohammed A K, Ali S A, Ali I F. Using locally Isolated Chlorella vulgaris in Wastewater Treatment. Eng. \&Tech. Journal. 2016; 34(4), Part (A): 762-768.

19. Reddy C N, Kakarla R, Min B. Algal Biocathodes. 2019; 525-547.

20. Song H, Zhang S, Long X, Yang X, Li H, Xiang W. Optimization of bioelectricity generation in constructed wetland-coupled microbial fuel cell systems. Water Journal. 2017; 9(185):1-13.

21. Khater D, El-khatib K M, Hazaa M, Hassan R Y A. Activated Sludge-based Microbial Fuel Cell for Bioelectricity Generation. Bas. \& Environ. Sci. 2015; 2: 63-73.

22. Pocaznoi D, Calmet A, Etcheverry L, Erable B, Bergel A. Stainless steel is a promising electrode material for anodes of microbial fuel cells. Energy Environ. Sci. 2012; 5(11): 9645-9652.

23. Firas Khaled. Contribution to electrical valorization of microbial fuel cells, $\mathrm{PhD}$ thesis, L'Institut National des Sciences Appliquées de Lyon. 2016.

24. Del Campo G, Lobato J, Cañizares P, Rodrigo M, Fernandez M F. Short-term effects of temperature and COD in a microbial fuel cell. Appl. Energy. 2013; 101: 213-217.

25. Martin E, Savadogo O, Guiot S R, Tartakovsky B. The influence of operational conditions on the performance of a microbial fuel cell seeded with mesophilic anaerobic sludge. Biochem. Eng. J. 2010; 51(3): 132-139.

26. Li M, Zhou M, Tian X, Tan C, McDaniel T C, Hassett D J, et al. Microbial fuel cell (MFC) power performance improvement through enhanced microbial electrogenicity. Biotechnol. Adv. 2018; 36: 1316-1327. 
تحسين إداء المسطحات المائية الصناعية المدمجة مع الخلية المايكروبية لتوليد الطاقة الكهربائية بإستخدام أقطاب من الفولاذ المقاوم للصدأ

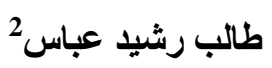

علاء كريم محمد

يسر ظافر عبد الوهاب1

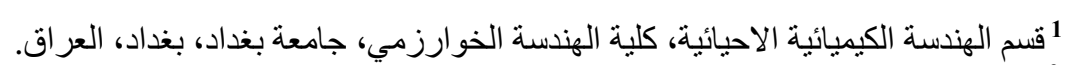

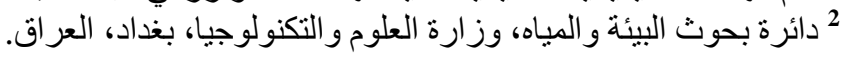

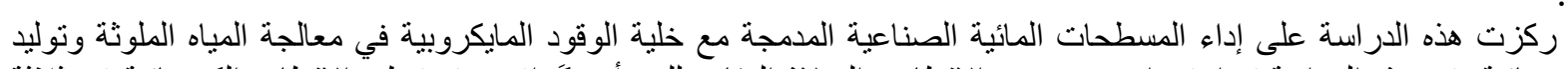

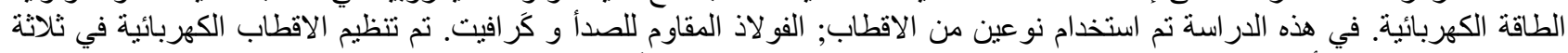

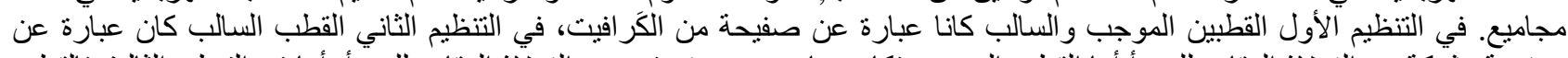

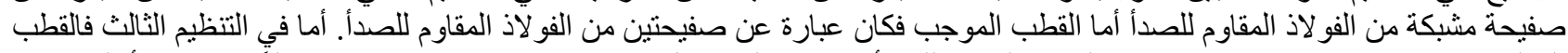

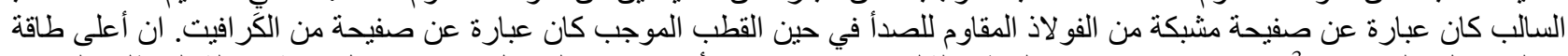

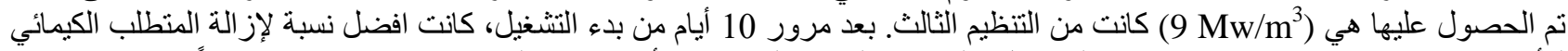

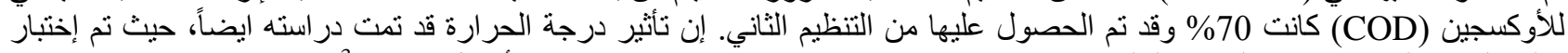
توليد الطاقة الكهربائية من التنظيم التالث في درجات حرانة حر ارة 40 درجة مئوية. في هذه الأنظمة الثناثة تم السماح للطحالب بالنمو حتى تزود هذه الأنظمة بالأوكسجين اللازم لعملية الاختز ال. الكلمات المفتاحية: ازالة COD، الأراضي الرطبة المشيدة، نوليد الكهرباء، خلايا الوقود الميكروبية، معالجة مياه الصرف. 